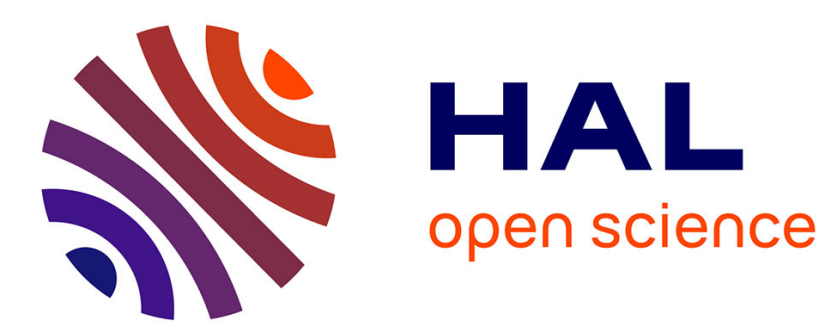

\title{
On some problems in plastic instabilities and strain localization (Moderator's Comment)
}

\author{
H. Neuhäuser
}

\section{To cite this version:}

H. Neuhäuser. On some problems in plastic instabilities and strain localization (Moderator's Comment). Revue de Physique Appliquée, 1988, 23 (4), pp.571-572. 10.1051/rphysap:01988002304057100 . jpa-00245804

\section{HAL Id: jpa-00245804 https://hal.science/jpa-00245804}

Submitted on 1 Jan 1988

HAL is a multi-disciplinary open access archive for the deposit and dissemination of scientific research documents, whether they are published or not. The documents may come from teaching and research institutions in France or abroad, or from public or private research centers.
L'archive ouverte pluridisciplinaire HAL, est destinée au dépôt et à la diffusion de documents scientifiques de niveau recherche, publiés ou non, émanant des établissements d'enseignement et de recherche français ou étrangers, des laboratoires publics ou privés. 


\title{
On some problems in plastic instabilities and strain localization (Moderator's Comment)
}

\author{
H. Neuhäuser
}

Institut für Metallphysik und Nukleare Festkörperphysik, Technische Universität, 3300 Braunschweig, F.R.G.

The heterogeneous dislocation structure emphasized in many earlier presentations in this conference implies a heterogeneity of shear which in extreme cases may lead to pronounced localization of strain. A complete description of these situations involves strain $\varepsilon(x, t)$ and strain rate $\dot{\varepsilon}(x, t)$ as dependent on position $x$ and $t i m e t$

Instabilities occur on different scales: in microscale as jerky motion of dislocations and of dynamic dislocation groups; in mesoscale as development of slip lines up to slip bands, and of microbands up to shear bands; in macroscale as PLC and Lüders bands, necking and failure. The reviews by L.P.Kubin [1] and A. Needleman [2] in this volume essentially cover the micro- to macroscale, and the macroscale, respectively.

A number of microscopic mechanisms are known to initiate plastic instabilities. They may be classified [3] into various dislocation mechanisms, diffusionless structural transformations, stresses by local imperfections, and local softening. Evidently all of these reasons for plastic instabilities tend to concentrate shear to a small volume of the material, i.e. tend to strain localization. Often cooperative synergetic processes [4] are involved which, due to their highly nonlinear behaviour, lead to the formation of characteristic patterns of shear [5].

Beautiful examples of the propagation of PLC bands in Al-Mg polycrystalline sheets were shown by L.P.Kubin on video tape ( $c f$. [6]), with characterisitc changes according to the external deformation rate. The question on the certain angle of the band in the sheet was raised; according to [7] it should be oriented in the direction of nonextensional deformation, cf. [8].

In another video film A.Korbel showed an example of extremely serrated flow of $\langle 112\rangle$ oriented Cu-Al crystals predeformed to high stresses, with plastic instabilities accompanied by audible clicks and discussed in terms of the removal of strong obstacles (dislocation reaction products) by slip on the critical plane enabling an avalanche of slip to develop [9].
The evolution of a plastic instability $\varepsilon(t)$ is difficult to describe; it involves inertia and wave propagation properties of the whole mechanical system. Only few successful attempts have been made as yet to investigate the process experimentally (e. g. $[10,11])$. Fortunalely, for many applications it is sufficient to know the generation rate $\dot{N}_{\text {in }}$ and the strain $\Delta \varepsilon_{i}$ developed during each instable event. The imposed strain rate then is given by $\dot{\varepsilon}=$ N $\Delta \varepsilon_{\text {in }}$, as already stated by orowan $\left[\mathrm{l}_{2}\right]$, and we have to find out which processes govern $N_{i n}$ and linit $\Delta \varepsilon_{\text {in }}$.

If the response of the material to stress is taken as given even locally, the evolution of plastic strain, including instabilities and localization, can be well calculated by finite element methods as shown by A. Needleman [2]. The discussion of this paper concentrated on the strain rate sensitivity of the yield surface. Certainly, independence on strain rate is an exceptional case in practice. Further, the problems of a vertex in the yield surface and attempts to explain it physically, were discussed.

In his contribution B.Pecherski considered the initiation of shear bands by perturbed plastic spin [13], which may correspond to the fluctuations of lattice rotation in microbands.

Finally, we wish to raise the problem of constitutive modeling of deformation, in particular if high local strains are involved. Usually in finite element codes parameters from experimental deformation laws are taken which have been derived from macroscopic measurements using average strain and work hardening rate. We know from microscopic observations that shear in crystalline materials is confined to a very small "active slip volume" $[14,3]$ where extremely high local strains are reached already at small average strain. Unfortunately, the active slip volume is not just a scaling factor but in general a function of the deformation conditions. Thus we feel that for realistic modeling the local strains should be measured (e.g. by methods being developed in [15]) and taken into account in the constitutive equations to be used for the calculations. 
References

[1] L.P.Kubin, this volume

[2] A.Needleman, this volume

[3] H. Neuhäuser, in: Mech.Prop. and Behav. of Solids: Plast. Instabilties (Eds. V.Balakrishnan, C.E.Bottani) World Scientific, Singapore 1986, p.209

[4] H.Haken, Synergetics, Springer, Berlin 1977

[5] E.C.Aifantis, Mat.Sci.Eng.81 (1986) 563

[6] K.Chihab, Y.Estrin, L.P.Küin, J.Vergnol, Scripta Met. (in press)

[7] U.F.Kocks, Progr.Mat.Sci., Chalmers Anniversary Volume, Pergamon, 1981, p.185

[8] A.S.Argon, in: The Inhomogeneity of
Plastic Deformation (Ed.R.E. Reed-Hill) ASM, Metals Park, Ohio 1972, p.161

[9] A.Korbel, this volume

[10] R.B.Schwarz, J.W.Mitchell, Phys.Rev.B 9 (1974) 3292; R.B.Schwarz, L.Funk, Ácta Met. $31 \quad$ (1983) 299

[11] V.V.Demirsiki, S.N.Komnik, Acta Met. 30 (1982) 2227

[12] E. Orowan, Proc.Phys.Soc.Lond. $\underline{5} \underline{2}$ (1940) 8

[13] B.Pecherski, this volume

[14] Ch.Schwink, phys.stat.sol.18 (1966) 557

[15] C.Rey; Ph.Dubois, C.Rey, this volume 